\title{
Extended lactations in a seasonal-calving pastoral system of production to modulate the effects of reproductive failure
}

\author{
S. T. Butler, ${ }^{1}$ L. Shalloo, and J. J. Murphy \\ Teagasc, Moorepark Dairy Production Research Centre, Fermoy, Co. Cork, Ireland
}

\begin{abstract}
This study was conducted to determine whether extending the calving interval (CI) to 24 mo would be an alternative to culling and replacing cows that had failed to become pregnant. Forty-six nonpregnant lactating cows were assembled in November 2004 and assigned to receive either $3 \mathrm{~kg}$ (low) or $6 \mathrm{~kg}$ (high) of concentrate supplement and a basal diet of grass silage and maize silage over the winter period (13 wk). Cows returned to pasture in late March and received $1 \mathrm{~kg}$ of concentrate/d until dry-off (milk yield $<5 \mathrm{~kg} / \mathrm{d}$ ). $\mathrm{Cu}$ mulative milk production was calculated from calving to the end of November 2004 (12-mo CI) and from the start of December 2004 until dry off in 2005 (extended lactation part of 24-mo CI). High winter feeding resulted in greater milk production over the winter confinement $(20.0 \pm 0.3$ vs. $17.8 \pm 0.3 \mathrm{~kg} / \mathrm{d}$ for high and low winter feeding, respectively) and had a carryover effect during the remainder of the 24 -mo CI period ( 5,177 vs. 4,686 $\mathrm{kg} ; \mathrm{SEM}=173 \mathrm{~kg}$ ). At the end of the study, cows were ranked on cumulative milk solids and separated into 3 groups (R1, R2, and R3). During the 24-mo CI, milk yields were $7,287,6,267$, and $5,273 \mathrm{~kg}(\mathrm{SEM}=308 \mathrm{~kg})$ in $\mathrm{yr} 1$, and $5,738,4,836$, and 4,266 $(\mathrm{SEM}=241 \mathrm{~kg})$ in yr 2 for R1, R2, and R3, respectively. Eighty-five percent of the cows became pregnant during the breeding season of yr 2, with a conception rate to first service of $52 \%$. An economic analysis of different ranks with a 12-mo CI, a 24-mo CI, and an annualized herd effect, which compared an efficient spring calving system with $30 \%$ recycled cows in $\mathrm{R} 1$ and $10 \%$ recycled cows in R3, was carried out. Farm profit was reduced by $60 \%$ and $65 \%$ at a milk price of 22.3 euro-cents (c)/L with the corresponding values of $17 \%$ and $30 \%$ for a milk price of $30 \mathrm{c} / \mathrm{L}$, respectively, when R1 and R3 systems were compared with an efficient spring milk (12-mo CI) production system. Within a spring system where $30 \%$ and $10 \%$ of R1 and R3 animals were subjected to extended lactations, the profit difference was reduced
\end{abstract}

Received May 21, 2009.

Accepted October 22, 2009.

${ }^{1}$ Corresponding author: stephen.butler@teagasc.ie compared with an efficient spring system, The results indicated that lactations with a 24-mo CI may be a viable alternative to culling nonpregnant cows and be economically more suited to higher producing cows.

Key words: extended lactation, pasture, milk production, profitability

\section{INTRODUCTION}

The use of AI in conjunction with intensive genetic selection programs has resulted in marked improvements in the productive efficiency of dairy cows (Bauman et al., 1985). Genetic improvement for milk production increased, particularly from the 1970s onward, and this improvement has continued in a linear fashion (Foote, 1996). Increased milk production was associated with a decline in reproductive performance, and the underlying basis of the compromised fertility remains poorly understood. Higher milk production is achieved by higher DMI and preferential partitioning of nutrients to the mammary gland at the expense of body reserves. High-producing cows mobilize body condition in early lactation and continue further into lactation before beginning to repartition nutrients to body reserves. Although this is associated with improved feed efficiency, it is antagonistic to the biological signals necessary for a successful pregnancy (Berry et al., 2003; Buckley et al., 2003). It is clear that the continuing trend of increasing genetic potential for milk production is associated with a progressive reduction in reproductive performance.

Efficient seasonal grass-based systems of milk production require compact calving coinciding with return to pasture (Dillon et al., 1995), necessitating excellent reproductive performance in a breeding season of similar duration to the desired calving period. The fertility and survival of pasture-based dairy cows in Ireland declined during the interval from 1990 to 2001 (Evans et al., 2006), consistent with other reports of declining fertility from the UK (Royal et al., 2000), the Netherlands (van Knegsel et al., 2005), and the United States (Butler, 2003). Declining reproductive performance had a negative effect on the profitability of all systems of milk production (Esslemont et al., 2001), but the necessity of a compact calving period for successful seasonal 
grass-based milk production has resulted in unacceptably high culling rates due to reduced fertility, eroding the advantage of lower costs of production.

A 305-d lactation is generally recognized as the optimum lactation length, allowing a 12-mo calving interval (CI), with 10 mo of high milk production and a 2-mo dry period. Yet, modern high-producing cows continue to have high milk production at $305 \mathrm{~d}$, the time of typical dry off. Recently, there has been interest in Australia and New Zealand in examining the potential role of extended lactations with a 24-mo CI on pasture-based systems of production (Auldist et al., 2007; Kolver et al., 2007). A study was undertaken at Moorepark Research Centre (Fermoy, Ireland) to address the following questions: 1) can cows lactate for 22 mo and calve every $2 \mathrm{yr} ; 2$ ) is there a milk production response to greater concentrate supplementation during the winter period of indoor feeding; 3) what is the milk potential of cows in the extended lactation compared with the first $305 \mathrm{~d}$; 4) would cows have good reproductive performance in the second year of lactation; and 5) would it be profitable?

\section{MATERIALS AND METHODS}

\section{Study Animals}

Forty-six spring-calving cows that had failed to become pregnant during the preceding breeding season (average 2.8 services/cow; range $=1$ to 6 ) were assembled from 3 Moorepark herds in November 2004 (average 264 DIM; range 197 to 313). In Ireland, it is typical for nonpregnant spring-calving cows to be dried off and culled at this time of the year, but for the purposes of this study, lactation was continued through the confinement winter feeding period and the following grazing season. Cows were milked twice daily, and milk yield was recorded at each milking during the entire lactation. Milk composition (fat, protein, and lactose) was determined once weekly. Body condition score was recorded every 2 wk. Cows were dried off when daily milk yield was $<5 \mathrm{~kg}$ or at 2 mo before calving, whichever occurred first. For all cows, the mean ( \pm SEM) proportion of Holstein genetics was $81 \pm 2.4 \%$, parity was $2.9 \pm 0.3$, predicted difference for milk production was $+225 \pm 31 \mathrm{~kg}$, the overall Economic Breeding Index $(\mathbf{E B I})$ value was $€ 42 \pm 4.8$, and the mean EBI sub-index value for milk solids production was €37.5 \pm 2.1 .

\section{Winter Feeding Treatment}

Cows were paired on the basis of parity, DIM, previous milk production, and BCS. They were then randomly assigned to receive either low $(3 \mathrm{~kg} / \mathrm{d}$ per cow; low winter feeding) or high $(6 \mathrm{~kg} / \mathrm{d}$ per cow; high winter feeding) amounts of concentrate supplementation over a 13 -wk winter feeding period commencing in December 2004. A basal diet of $50 \%$ grass silage and $50 \%$ maize silage (DM basis) was offered ad libitum to both treatments. Cows were returned to pasture on March 31, and from then until the end of lactation all cows were offered $1 \mathrm{~kg} / \mathrm{d}$ of concentrate. The $\mathrm{CP}$ and $\mathrm{NE}_{\mathrm{L}}$ of the concentrate fed were $186 \pm 71 \mathrm{~g} / \mathrm{kg}$ and 1.0 UFL (unité fourragère lait) $/ \mathrm{kg}$, respectively.

\section{Ranking Based on Cumulative Milk Production}

Large variation in milk yield between cows was observed throughout lactation. When all cows had finished milking, cumulative milk solids production (CMSP) from calving to dry-off was calculated for each cow, and cows were ranked on the basis of CMSP. The cows were then separated into 3 ranks: $\mathbf{R} \mathbf{1}=15$ highest CMSP; $\mathbf{R 2}=15$ intermediate CMSP; and $\mathbf{R 3}=16$ lowest CMSP. The mean predicted difference for milk production was $225 \pm 31,242 \pm 38$, and $125 \pm 31 \mathrm{~kg}$ for R1, $\mathrm{R} 2$, and R3, respectively. The number of cows in the low and high winter feeding treatments was 6 and 9,7 and 8 , and 10 and 6 , for R1, R2 and R3, respectively.

\section{Lactation Persistency}

A measure of lactation persistency was calculated for all cows during the 12-mo CI period and during the extended lactation portion of the 24-mo CI period. During the 12-mo CI period, persistency was calculated by subtracting weekly milk yield at the end of the 12mo period from weekly milk yield at peak, and dividing by the number of weeks between peak yield and the end of the 12-mo period. All cows had a characteristic second peak during the confined winter feeding period. During the extended portion of the 24-mo CI period, persistency was calculated by subtracting weekly milk yield at the end of the extended lactation period (i.e., at time of dry-off, approximately $20 \mathrm{mo}$ ) from weekly milk yield at the second peak, and dividing by the number of weeks between the second peak yield and the end of the extended lactation period.

\section{Reproductive Measures}

The second breeding season began on April 18 and ended on July 18, 2005. Tail paint was used as an estrus detection aid (applied 2 to 3 times weekly), and all cows were inseminated based on visual detection of standing estrus, removal of tail paint, or both. Cows were 405 DIM (range 336 to 452) on the AI start date. Transrec- 
tal ultrasonography of the reproductive tract was carried out before the start of the breeding season to assess the ovarian and uterine status. The only abnormality observed was that 4 cows had cystic ovarian disorder $(2$ from the low concentrate and 2 from the high concentrate winter feeding treatments; 3 from $\mathrm{R} 1$ and 1 from R3 CMSP ranks). Cows with cystic ovarian disorder were treated with the following program: GnRH and controlled intravaginal drug releasing (CIDR) device inserted (d 0), $\mathrm{PGF}_{2 \alpha}$ (d 9), CIDR removal (d 10), and $\mathrm{AI}$ at standing heat or fixed-time AI $48 \mathrm{~h}$ after CIDR removal. The GnRH injections were $5 \mathrm{~mL}$ of Receptal (20 $\mu \mathrm{g}$ of buserelin; Intervet Ireland, Dublin, Ireland), the $\mathrm{PGF}_{2 \alpha}$ injections were $2 \mathrm{~mL}$ of Estrumate $(500 \mu \mathrm{g}$ of cloprostenol sodium; BP (Vet) Coopers, Berkhamsted, UK), and the CIDR contained $1.94 \mathrm{~g}$ of progesterone (InterAg, Hamilton, New Zealand). The timing of the program facilitated breeding on the first day of the breeding season. Pregnancy diagnosis was carried out using transrectal ultrasonography at 30 to 36 and 60 to 66 d post-AI (Aloka 900, 7.5-MHz transrectal transducer; Aloka, Tokyo, Japan).

\section{Data Handling and Statistical Analysis}

All data analyses were carried out using SAS (SAS Institute Inc., Cary, NC). The daily measurements of milk yield were collapsed into weekly means, and mean daily yields of milk fat, protein, and lactose were calculated for each week. For the analysis of the effect of the winter feeding treatment on milk production, high or low winter feeding was compared using repeated measures and the MIXED procedure from the beginning until the end of the period of differential feeding ( $13 \mathrm{wk}$ ). The model contained treatment, week, and the interaction of treatment and week as fixed effects, and block as a random effect. Week was used in the repeated statement, and an autoregressive covariance structure was used. Cumulative milk production from the beginning of the feeding treatments until dry off was calculated for each cow, and the effect of winter concentrate feeding was analyzed using PROC MIXED with treatment as a fixed effect and lactation length, parity, and previous milk production from calving until initiation of winter feeding treatment used as adjustment variables. Block was included as a random effect. The milk production and BCS of the different CMSP ranks was compared using PROC MIXED with rank as a fixed effect, and the data adjusted for winter feeding treatment and parity. The effects of winter feeding treatment and rank on lactation length were compared using survival analysis (PROC LIFETEST). Differences in lactation persistency were compared using PROC MIXED. The model for winter feeding treatment contained the fixed effects winter feeding treatment and parity, and block was included as a random variable. The model for milk production rank contained the fixed effect Rank, parity and winter feeding treatment.

Pearson correlation coefficients (PROC CORR) were used to evaluate the relationship between animal factors (parity 1, 2, or $>2$; proportion of Holstein genetics; PTA for milk yield; and EBI value for milk solids production) and various descriptors of the lactation curve profile [milk yield and milk solids yield from calving until 305 DIM, milk yield and milk solids yield from 305 DIM until dry off, milk yield at 305 DIM, lactation length, peak milk yield, week of peak milk yield, and persistency (100-d cumulative milk yield as a proportion of 305-d cumulative milk yield)]. Multiple linear regression (PROC REG) and the stepwise variable selection procedures were used to generate a model containing independent variables that were most effective at predicting cumulative milk yield and cumulative milk solids yield based on data available at 305 DIM. The significance level for entry and the significance level to stay in the model were both set at 0.05 .

\section{Economic Analysis}

The Moorepark Dairy Systems Model (Shalloo et al., 2004), which is a stochastic budgetary simulation model, was used to simulate the economic effect of several strategies involving extending the lactation of dairy cows. The model integrated animal inventory and value, milk production, feed requirement, land and labor utilization, and economic analysis. Biological data recorded in the $2 \mathrm{yr}$ were included in the model to determine the effect on profitability of a 12 -mo or a 24-mo CI.

Land area was treated as an opportunity cost with additional land rented when required and leased out when not required for on-farm feeding of animals. Variable costs [fertilizer, agricultural machinery contractor charges (silage, slurry), medical and veterinary costs, AI, silage harvesting, and pasture reseeding], fixed costs (machinery maintenance and running costs, farm maintenance, car, telephone, electricity, and insurance), and prices (calf, milk, and cow) were based on 2008 prices (Teagasc, 2008). The quantity of feeds consumed (grass, grass silage, and concentrate) was determined by the Moorepark Dairy Systems Model to meet the $\mathrm{NE}_{\mathrm{M}}, \mathrm{NE}_{\mathrm{L}}$, and $\mathrm{NE}_{\mathrm{G}}$ (Jarrige, 1989). The key herd default measures used in the model farm are in Table 1. Milk output from the farm was maximized with a limitation on land of 40 ha; therefore, a further increase in milk production would require the purchase of additional feed. 
Table 1. Assumptions used in the model farm to study extended lactations in a seasonal-calving pastoral system

\begin{tabular}{lcc}
\hline Item & Year 1 & Extended Year 2 \\
\hline Farm size (ha) & 40 & 40 \\
Reference fat $(\mathrm{g} / \mathrm{kg})$ & 36 & 36 \\
Gross milk price $(\mathrm{low})\left(\mathrm{c}^{1} / \mathrm{kg}\right)$ & 22.3 & 22.3 \\
Gross milk price (high) $(\mathrm{c} / \mathrm{kg})$ & 30.0 & 30.0 \\
Price ratio protein to fat & 2.00 & 2.00 \\
Replacement heifer price $(€)$ & 1,550 & 1,550 \\
Reference cull cow price $(€)$ & 400 & 750 \\
Reference male calf price $(€)$ & 108 & - \\
Labor cost per unit $(€)$ & 22,800 & 22,800 \\
Labor requirements per cow/year $(\mathrm{h})$ & 42 & 35 \\
Concentrate costs $(€ / \mathrm{t})$ & 250 & 250 \\
Opportunity cost of land $(€ /$ ha) & 375 & 375 \\
\hline
\end{tabular}

${ }^{1} \mathrm{c}=$ euro cent.

Replacement heifer costs were estimated at $€ 1,550$ (all costs including capital, land, and labor). All male and $55 \%$ of female calves were sold at 1 mo of age. The proportion of cows removed from the herd in each rank accounted for cows that failed to become pregnant by the end of the breeding season as well as voluntary culling and cow mortality. Based on the different cow BW at the end of a 305-d lactation or an extended 660d lactation, it was assumed that cull cow values were $€ 400$ and $€ 750$, respectively.

Because of the impending removal of European Union milk quotas and the current uncertain future for milk price, 2 economic scenarios were investigated. In scenario 1 it was assumed that land was fixed at 40 ha with the only means of increasing milk output from the farm being through increased purchased feed input at a low milk price of 22.3 euro-cents (c)/L. In scenario 2 it was assumed that land was fixed at 40 ha with the only means of increasing milk output from the farm being through increased purchased feed input, but the analysis was carried out at a milk price of $30.0 \mathrm{c} / \mathrm{L}$. The milk prices computed were based on a protein content of $33 \mathrm{~g} / \mathrm{kg}$ and a fat content of $36 \mathrm{~g} / \mathrm{kg}$ with a price ratio of $2: 1$ for protein:fat.

The analysis compared R1 (highest CMSP), R3 (lowest CMSP), and an efficient grass-based spring-calving system with 12-mo CI. For R1 and R3 animals it was assumed that there was an initial 10-mo lactation followed by an extended lactation period of an additional 12 mo. Genetic merit for milk yield and phenotypic milk yield were greater for R1 cows compared with R3 cows. It was assumed that a herd of $\mathrm{R} 1$ cows would have lower reproductive performance compared with a herd of R3 cows. The R1 group of cows was assumed to have a $40 \%$ replacement rate if forced into a 12 mo CI, whereas the R3 group was assumed to have a lower replacement rate of $17 \%$ (Buckley et al., 2003; Kennedy et al., 2003; McCarthy et al., 2007). All data in relation to the efficient spring (ES) calving system originated from a Holstein-Friesian genotype with a New Zealand origin with a stocking rate of 2.47 cows/ ha with $350 \mathrm{~kg}$ of purchased supplement based on data from McCarthy et al. (2007). These data were based on a 5-yr study carried out between 2000 and 2005 in which 3 genotypes were compared across 3 grass-based feed systems. When analyzing the data for R1 and R3 animals in a 2-yr lactation, it was assumed that there would be a culling rate of $12 \%$ in the first $305-\mathrm{d}$ period followed by an additional culling rate of $20 \%$ during or at the end of the 24-mo period for both groups of animals. The culling rate of $12 \%$ during the first $305 \mathrm{~d}$ was included to account for losses during lactation and cows that would be deemed unsuitable for a 24-mo lactation (SCC, lameness, and age). The $20 \%$ culling rate at the end of the 24-mo lactation period was based on a proportion of cows failing to establish pregnancy in addition to some voluntary culling for the same reasons outlined above.

The analysis compared the 3 groups of animals individually, first in a system with a 12-mo CI and subsequently in a system where the annualized herd effects were captured when the lactation length was extended to $24 \mathrm{mo}$. In this scenario it was possible to achieve a direct comparison of milk production systems where animals were in a system with a 12 -mo CI versus a system where extended lactation was employed to maintain nonpregnant animals in the herd. To compare R1, R3, and an ES group in a 12-mo CI with systems that had 24-mo lactations, it was assumed that $30 \%$ of $\mathrm{R} 1$ and $10 \%$ of R3 animals would have to be recycled to maintain the system. Therefore, R1, R3, and the ES system with 12-mo CI were compared with R1 and R3 animals in a system where $30 \%$ and $10 \%$ of the animals had a 24-mo CI, respectively.

\section{RESULTS}

\section{Reproductive Performance During Normal and Extended Lactation Periods}

During the breeding season of the 12-mo lactation period (yr 1), the interval ( \pm SEM) from calving to first AI was $66.8 \pm 4.6 \mathrm{~d}$ (range: 13 to $165 \mathrm{~d}$ ). The number of services per cow was $2.8 \pm 0.2$ (range: 1 to 6 services/cow). Forty cows had at least 2 AI, and the return interval after first AI was $33.8 \pm 2.2 \mathrm{~d}$ (range: 16 to $82 \mathrm{~d}$ ). The proportion of cows that returned to estrus during the 18- to 24-d interval after AI was $30.0 \%$, and the proportion of repeat AI occurring after d 24 was $67.5 \%$. There were no differences between the different milk production ranks for any of the variables outlined above in yr 1. During the breeding season of the 24- 
A)

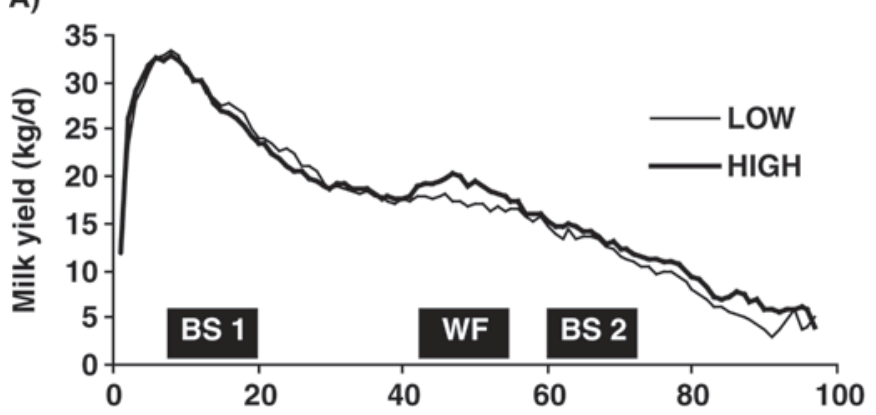

B)

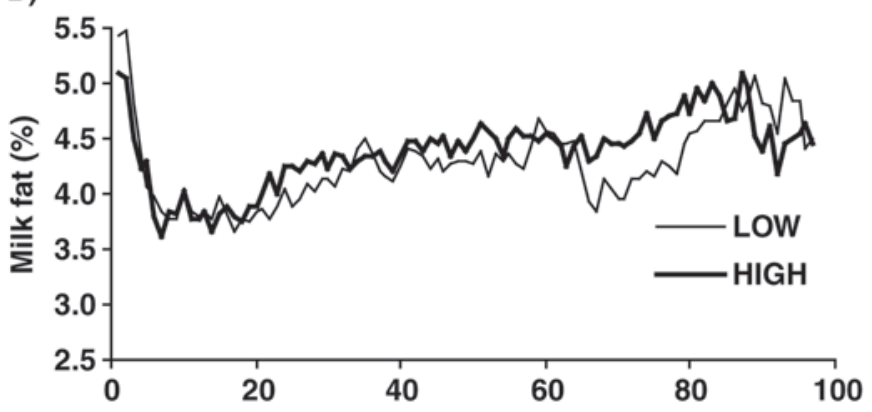

C)

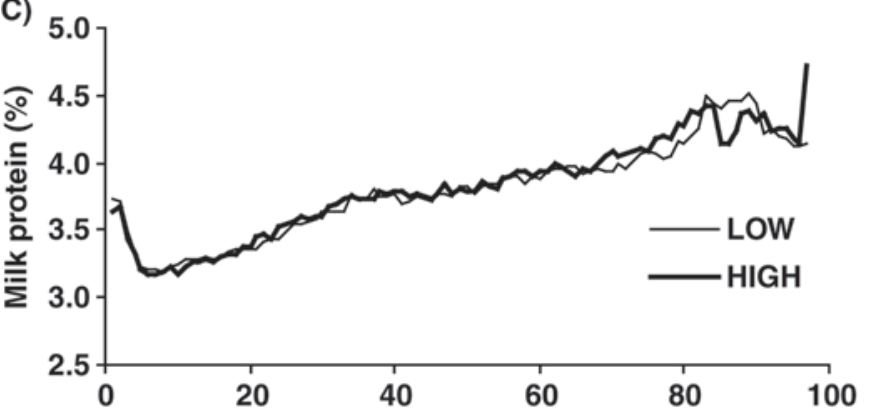

D)

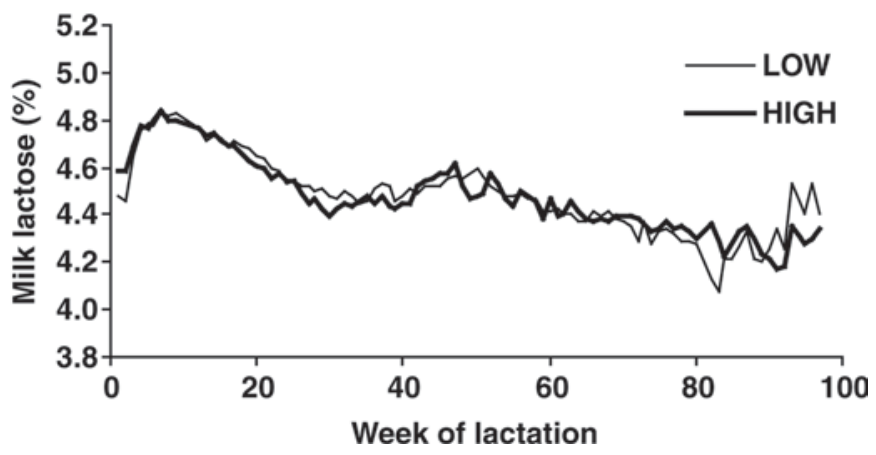

Figure 1. Milk production and component profiles during the 22 mo extended lactation of cows offered low $(3 \mathrm{~kg})$ or high $(6 \mathrm{~kg})$ levels of concentrate supplement during the winter confinement housing period. The approximate times of the first breeding season (BS 1), the winter feeding treatment (WF), and the second breeding season (BS 2) are indicated by the solid bars. mo lactation period (yr 2), the interval from calving to first AI was $415 \pm 5.5 \mathrm{~d}$ (range: 337 to 491 ). The AI submission rate in the first 3 wk of the breeding season was $87 \%$, the pregnancy rate to first service was $52 \%$, the 6 -wk pregnancy rate was $65 \%$, and during the 13-wk breeding season, $85 \%$ of the cows became pregnant. The number of services per cows was $1.82 \pm$ 0.17 (range: 1 to 7 ), and the number of services per cow that conceived was $1.51 \pm 0.11$ (range: 1 to 3 ). There were no differences between the different winter feeding treatments or the different milk production ranks for any of the reproduction variables outlined above in yr 2.

\section{Effect of Winter Feeding on Milk Production}

The level of concentrate supplementation during the confinement winter feeding period had a significant effect $(P<0.001)$ on milk production $(19.9 \pm 0.6$ vs. $17.6 \pm 0.6 \mathrm{~kg} / \mathrm{d}$ for high vs. low winter feeding treatments, respectively; Figure 1 and Figure 2), resulting in a total milk production response of $209 \mathrm{~kg}$ of milk during the 13 -wk period of confinement concentrate supplementation $(0.77 \mathrm{~kg}$ of milk/d per additional $\mathrm{kg}$ of concentrate supplement). Cumulative milk production from the beginning of the confinement feeding period until the end of lactation was increased by 462 $\mathrm{kg}(5,355 \pm 217$ vs. $4,912 \pm 223 \mathrm{~kg} ; P=0.04)$. This increase in cumulative milk production equated to 1.69 $\mathrm{kg}$ of milk per additional $\mathrm{kg}$ of concentrate supplement, indicating a carryover effect of $0.92 \mathrm{~kg}$ of milk/ $\mathrm{kg}$ of additional concentrate from the end of the high level of winter feeding until dry off. The effect of winter feeding treatment on milk production and lactation length is in Table 2 and Table 3, respectively. Winter feeding level did not affect lactation length (DIM $=593 \pm 12$ vs. $593 \pm 10 \mathrm{~d}$ for high and low, respectively; $P>0.5$ ). There was no difference in lactation persistency in the period before the winter feeding treatment, but cows on the high winter feeding treatment had a greater $(P<$ 0.01 ) weekly decline in milk yield during the extended lactation period (Table 2).

\section{Milk Production Based on Rank}

The milk production of the 3 ranks is given in Table 4 and Figure 3. The adjustment variable winter feeding level was not significant $(P>0.50)$, but parity tended to be significant $(P=0.08)$. The effect of milk production rank on lactation length is given in Table 3 and Table 4. An effect of rank on lactation length was observed $(P<0.01)$, with R3 having a shorter lactation length $(558 \pm 13 \mathrm{~d})$ compared with either R1 $(615 \pm 10$ d) or R2 $(609 \pm 13 \mathrm{~d})$. The weekly decline in milk yield 
Table 2. Effect of winter feeding treatment ${ }^{1}$ on milk production in extended lactations in a seasonal-calving pastoral system

\begin{tabular}{lcccl}
\hline Item & Low & High & SEM & $P$-value \\
\hline Calving to end Nov. 2004 & & & & \\
Cumulative milk yield (kg) & 6,332 & 6,176 & 260 & 0.7 \\
Cumulative milk fat (kg) & 256 & 250 & 10 & 0.7 \\
Cumulative milk protein (kg) & 217 & 211 & 9.8 & 0.6 \\
Milk yield decline from first peak (kg/wk) & 4.48 & 4.67 & 0.21 & 0.4 \\
Protein-to-fat ratio & 0.855 & 0.853 & 0.010 & 0.8 \\
DIM & 266 & 261 & 7.3 & 0.6 \\
Start Dec. 2004 to dry off & & & & \\
Cumulative milk yield (kg) & 4,686 & 5,177 & 173 & 0.05 \\
Cumulative milk fat (kg) & 200 & 230 & 8.6 & 0.02 \\
Cumulative milk protein (kg) & 181 & 201 & 6.1 & 0.03 \\
Milk yield decline from second peak (kg/wk) & 2.47 & 2.92 & 0.12 & 0.009 \\
Protein-to-fat ratio & 0.940 & 0.913 & 0.017 & 0.04 \\
DIM & 327 & 332 & 7.3 & 0.6 \\
Proportion of first period produced in second period & & & & \\
Milk yield & 0.74 & 0.84 & 0.05 & 0.18 \\
Milk fat & 0.78 & 0.92 & 0.06 & 0.11 \\
Milk protein & 0.83 & 0.95 & 0.06 & 0.16 \\
\hline
\end{tabular}

${ }^{1}$ Low $=$ low winter feeding treatment; high $=$ high winter feeding treatment.

did not differ between the milk production ranks during the 12 -mo or 24-mo lactation periods.

\section{BCS}

Body condition score data up to and including the normal time of dry-off were recorded before the animals commenced the extended 24-mo lactation study. The BCS results during the 2-yr lactation are in Table 5 . The winter feeding treatment did not affect BCS. The final BCS recorded at the end of feeding treatment for low and high feeding levels were $3.36 \pm 0.08$ and 3.38 \pm 0.08 , respectively $(P=0.9)$. Across all cows, BCS declined during early lactation and during the breeding period of yr 1, and remained relatively flat until the normal time of dry off after 10 mo of lactation. Thereafter, BCS increased steadily until actual dry-off in yr 2 . This resulted in a 0.45 -unit increase in BCS between the AI start date (mating start date, MSD) in yr 1 and MSD in yr $2(2.88 \pm 0.08$ vs. $3.33 \pm 0.08 ; P<0.001)$. The BCS at AI end date (mating end date, MED) was 0.8 units greater in yr 2 compared with in yr 1 (2.68 \pm 0.08 vs. $3.47 \pm 0.08 ; P<0.001$ ). Cows lost 0.2 units of BCS during the breeding period of yr 1, but gained 0.15 units of BCS during the breeding period of yr 2 . There was a significant effect of milk production rank on BCS during yr 1, with R3 cows having a higher BCS compared with R1 and R2 cows at MED and time of normal dry-off, respectively (Table 5). There were no differences in BCS between the milk production ranks during the extended period of the 24-mo lactation in yr 2.

\section{Correlation and Multiple Regression Analysis}

The correlation between cumulative milk output (volume and solids) and components of the lactation curve and animal factors are in Table 6 . The independent variables that were significantly correlated with cumulative milk yield were, with the exception of lactation persistency, also correlated with cumulative milk solids yield. The multiple regression models for predicting cumulative milk yield and cumulative milk solids yield over the combined normal and extended lactations are in Table 7. The independent variables selected for cumulative milk yield were cumulative 305-

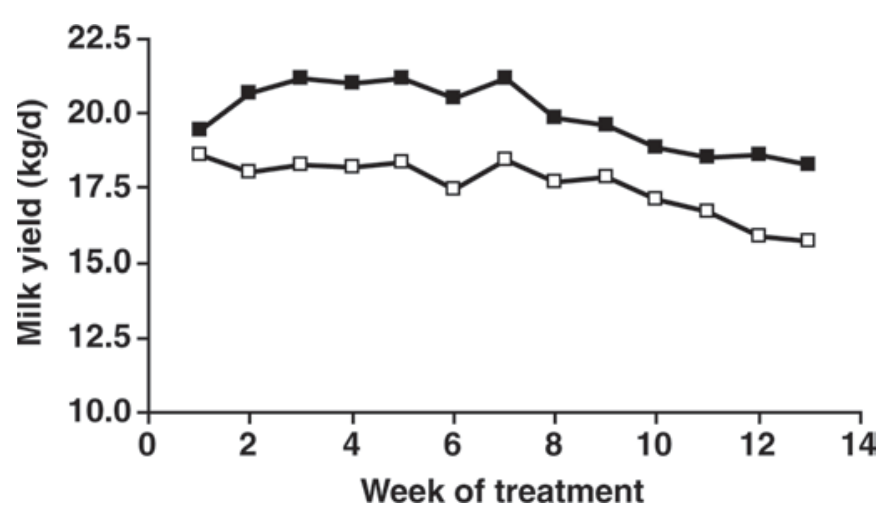

Figure 2. The effect of winter feeding treatment (high, $\mathbf{\square}$; low, $\square$ ) on daily milk yield in extended lactations in a seasonal-calving pastoral system. Significant effects of treatment $(P<0.001)$ and week $(P$ $<0.001$ ) were observed, but not for the interaction between treatment and week $(P=0.1)$. The pooled SEM was $0.63 \mathrm{~kg} / \mathrm{d}$. 
Table 3. The number (\%) of cows achieving lactations of increasing duration in extended lactations in a seasonal-calving pastoral system

\begin{tabular}{lccccc}
\hline & \multicolumn{5}{c}{ Lactation length $(\mathrm{d})$} \\
\cline { 2 - 6 } Item & 420 & 480 & 540 & 600 & 660 \\
\hline Winter feeding treatment & & & & \\
Low (n=23) & $23(100)$ & $23(100)$ & $20(87.0)$ & $11(47.8)$ & $3(13.0)$ \\
High (n=23) & $23(100)$ & $22(95.7)$ & $20(87.0)$ & $10(43.5)$ & $4(17.4)$ \\
Milk production rank ${ }^{2}$ & $15(100)$ & $15(100)$ & $15(100)$ & $10(66.7)$ & $2(13.3)$ \\
R1 (n=15) & $15(100)$ & $15(100)$ & $14(93.3)$ & $7(46.7)$ & $4(26.7)$ \\
R2 (n=15) & $16(100)$ & $15(93.8)$ & $11(68.8)$ & $3(18.8)$ & $1(6.3)$ \\
R3 (n=16) &
\end{tabular}

${ }^{1}$ Low $=$ low winter feeding treatment; high $=$ high winter feeding treatment.

${ }^{2} \mathrm{R} 1=15$ highest cumulative milk solids production $(\mathrm{CMSP}) ; \mathrm{R} 2=15$ intermediate CMSP; and R3 = 16 lowest CMSP.

d milk yield, PTA for milk yield, and mean weekly milk yield at 305 DIM. The independent variables selected for cumulative milk solids yield were cumulative 305-d milk solids yield, mean weekly milk yield at 305 DIM, and the categorical variable parity.

\section{Economic Analysis}

Individual Years. Table 8 shows the key herd output parameters from the model for an ES calving herd and R1 and R3 herds in a system with a 12-mo CI, and a system in which R1 and R3 herds had a 24-mo CI. In the 12-mo CI systems, the highest profit was achieved with the ES system irrespective of milk price (€29,731 compared with $€ 11,875$ and $€ 10,385$ for ES, $\mathrm{R} 1$, and $\mathrm{R} 3$ at a milk price of $22.3 \mathrm{c} / \mathrm{L}$, respectively; the corresponding figures at a milk price of $30.0 \mathrm{c} / \mathrm{L}$ were $€ 71,094$, €49,460, and €58,696, respectively). Milk price had an effect on all profitability indicators across the 3 systems. The increased farm profit for the ES system over both R1 and R3 was associated with lower concentrate supplementation $(316,857$, and $537 \mathrm{~kg}$ of $\mathrm{DM} /$ cow for the 3 groups respectively; higher milk fat and protein percentages (4.38 and $3.65 \%$ for ES; 4.13 and $3.49 \%$ for R1; 4.16 and $3.47 \%$ for R3); and lower replacement costs $(€ 22,834, € 49,797$, and $€ 23,692$ for the 3 groups, respectively) resulting in lower total costs (€148,106, €184,627, and €158,992 for the 3 groups, respectively).

When R1 and R3 were compared in a 24-mo CI system, there was a difference in profit in the first 305-d period compared with the standard ES system. This result arose because of a much reduced replacement cost, with the replacement rate being reduced from 40 to $12 \%$ for $\mathrm{R} 1$ animals and the replacement rate dropping from 17 to $12 \%$ for R3 animals in the first

Table 4. Effect of milk production rank $^{1}$ on milk production in extended lactations in a seasonal-calving pastoral system

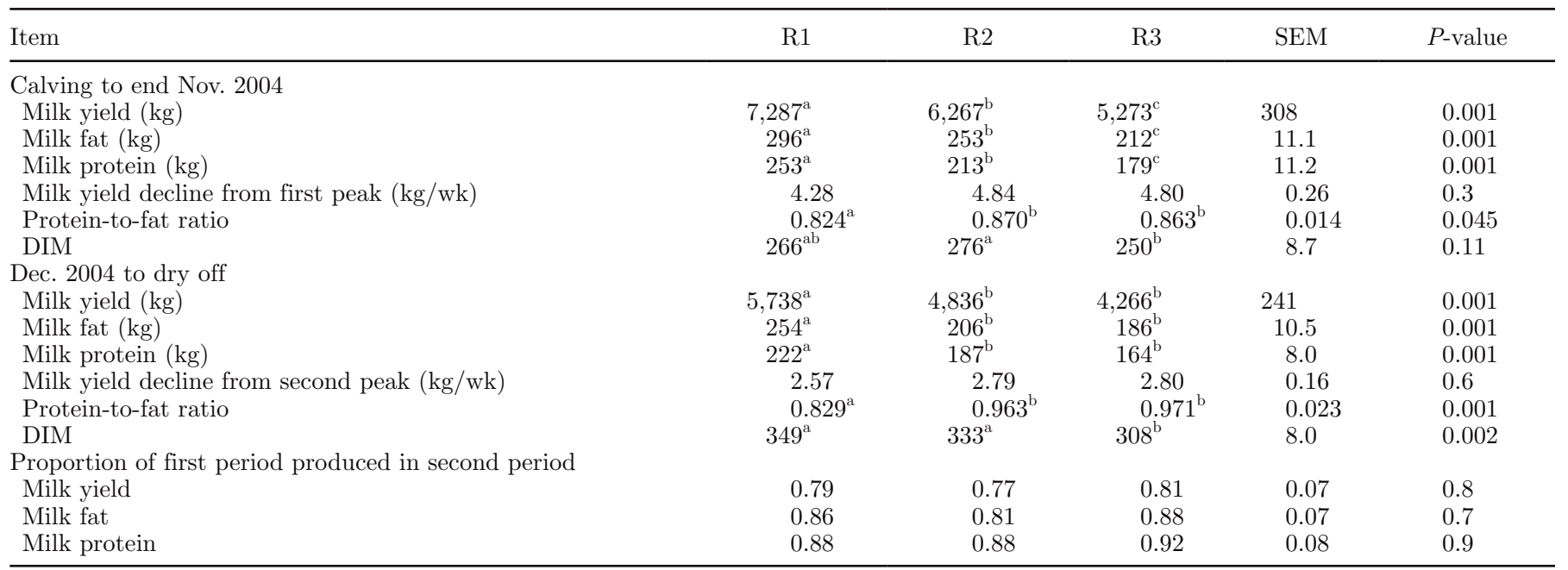

${ }^{\mathrm{a}-\mathrm{c}}$ Within-row means not sharing a common superscript differ $(P<0.05)$.

${ }^{1} \mathrm{R} 1=15$ highest cumulative milk solids production $(\mathrm{CMSP}) ; \mathrm{R} 2=15$ intermediate CMSP; and R3 = 16 lowest CMSP. 

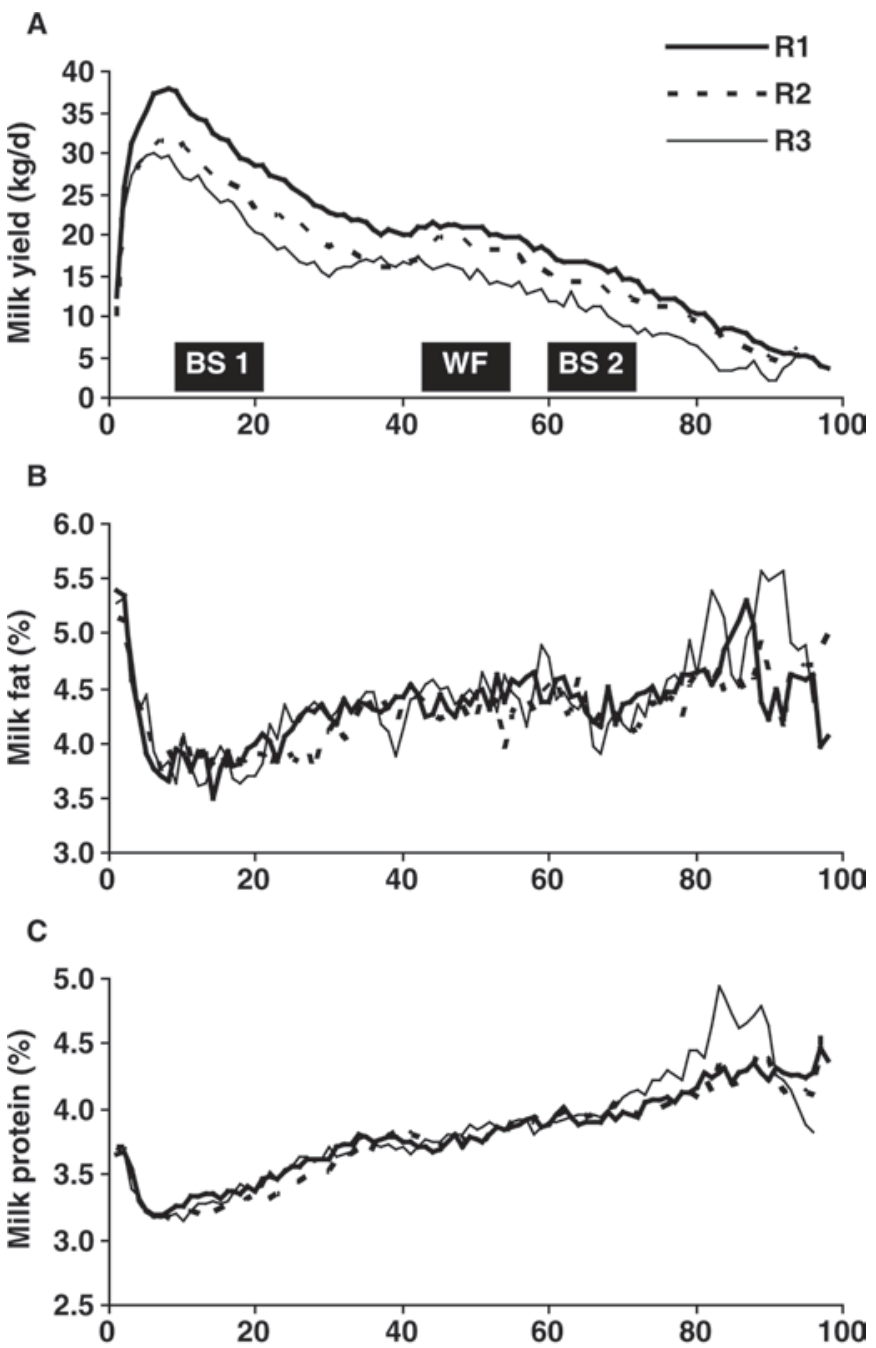$$
\text { D }
$$

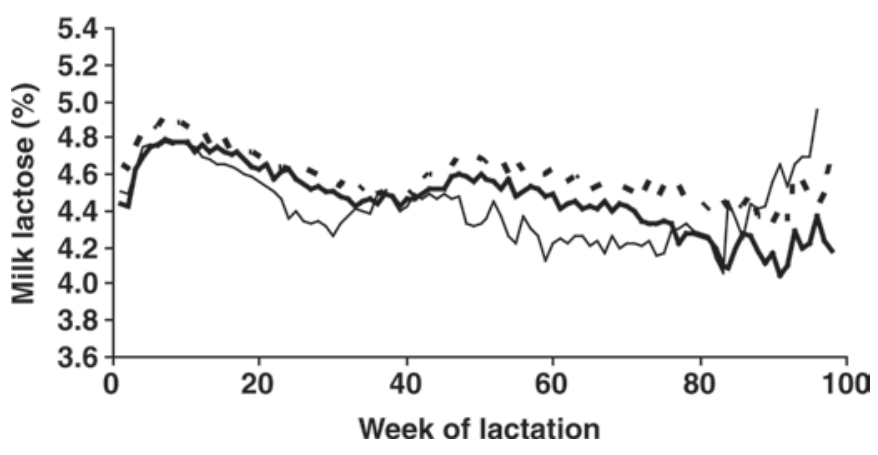

Figure 3. Milk production and component profiles during the 22mo extended lactation of cows separated into 3 ranks based on cumulative milk solids production (CMSP) during the entire lactation period in a seasonal-calving pastoral system. The approximate times of the first breeding season (BS 1), the winter feeding treatment (WF), and the second breeding season (BS 2) are indicated by the solid bars. $\mathrm{R} 1=15$ highest $\mathrm{CMSP} ; \mathrm{R} 2=15$ intermediate CMSP; and R3 = 16 lowest CMSP. 12-mo period. For both R1 and R3 animals, there was a financial loss in the extended lactation period at the low milk price ( $-€ 11,880$ and $-€ 47,739$, respectively), whereas at the higher milk price, R3 animals made a loss in the extended lactation period of the 24-mo CI system $(-€ 14,829)$ but $\mathrm{R} 1$ animals made a profit of $€ 28,578$. The reduction in profitability associated with the extended lactation period of the 24-mo CI system for both R1 and R3 animals was because of the higher costs of production with reduced milk sales.

Annualized Herd Effect. Table 9 shows the key herd annualized output parameters from the model for R1, R3, and an ES system with 12-mo CI, R1 animals where $30 \%$ of the animals had extended lactations and 24-mo CI, and a herd with R3 animals that contained $10 \%$ of the animals with extended lactations and 24-mo CI. At a milk price of $22.3 \mathrm{c} / \mathrm{L}$, the ES system had the best financial performance with a total farm profit of $€ 29,731$ compared with €11,875, €10,385, €22,870, and -€2,528 for R1 cows with a 12-mo CI, R3 cows with a 12 -mo CI, R1 in a system with $30 \%$ of cows having a 24 -mo CI, and R3 in a system with $10 \%$ of cows having a 24-mo CI, respectively. The corresponding figures for a milk price of $30.0 \mathrm{c} / \mathrm{L}$ were $€ 71,094, € 58,696, € 49,460$, $€ 67,782$, and $€ 34,697$, respectively. The ES system had the lowest costs of milk production and was more profitable than the alternative systems at a low milk price. The farm profit was $30.0 \%$ greater than the next most profitable system - R 1 with $30 \%$ of the cows having a 24-mo CI. At the higher milk price of $30 \mathrm{c} / \mathrm{L}$, the difference in profitability was much lower $(4.9 \%)$. Rank 1 animals became more profitable through extending the lactation of a proportion of the herd compared with culling and replacing $40 \%$ of the herd. The profitability of R3 animals was reduced by having a proportion of the animals with 24-mo lactations.

\section{DISCUSSION}

\section{Milk Production}

Average milk yield during the entire lactation period supported results from previous reports of extended lactations in pasture-based systems (Auldist et al., 2007; Kolver et al., 2007). A large effect of genetic potential for milk production on milk yield was observed, not just in the 12-mo CI period, but also in the extended lactation period of the 24-mo CI. Similarly, Kolver et al. (2007) reported that North American Holsteins had greater total milk production than New Zealand Holsteins, reflecting the emphasis placed on milk yield potential in the North American selection indices compared with the New Zealand selection index. Those authors reported greater responses to additional con- 
Table 5. Effect of winter feeding treatment and milk production rank on BCS in extended lactations in a seasonal-calving pastoral system ${ }^{1}$

\begin{tabular}{|c|c|c|c|c|c|c|c|}
\hline Item $^{2}$ & \multicolumn{2}{|c|}{ Winter feeding treatment ${ }^{3}$} & \multicolumn{3}{|c|}{ Milk production rank $^{4}$} & \multicolumn{2}{|c|}{$P$-value } \\
\hline Calving & 3.20 & 3.18 & 3.12 & 3.22 & 3.23 & 0.9 & 0.70 \\
\hline MED yr1 & 2.71 & 2.65 & $2.55^{\mathrm{a}}$ & $2.65^{\mathrm{ab}}$ & $2.83^{\mathrm{b}}$ & 0.9 & 0.05 \\
\hline Normal 305-d dry-off & 2.80 & 2.72 & $2.70^{\mathrm{ab}}$ & $2.65^{\mathrm{a}}$ & $2.92^{\mathrm{b}}$ & 0.9 & 0.06 \\
\hline MSD yr 2 & 3.30 & 3.36 & 3.23 & 3.25 & 3.50 & 0.9 & 0.30 \\
\hline
\end{tabular}

${ }^{\mathrm{a}, \mathrm{b}}$ Within a row, means for milk production rank differ $(P<0.05)$.

${ }^{1}$ Values in normal font were recorded in yr 1 before the initiation of the extended lactation study. Values in bold font were recorded in yr 2 during the period of extended lactation. Pooled SEM for effect of winter feeding treatment was 0.10; pooled SEM for effect of milk production rank was 0.12 .

${ }^{2} \mathrm{MSD}=$ mating start data; MED = mating end date.

${ }^{3}$ Low $=$ low winter feeding treatment; high $=$ high winter feeding treatment.

${ }^{4} \mathrm{R} 1=15$ highest cumulative milk solids production $(\mathrm{CMSP}) ; \mathrm{R} 2=15$ intermediate CMSP; and R3 = 16 lowest CMSP.

centrate supplementation in North American Holsteins compared with New Zealand Holsteins, in agreement with previous reports with 12-mo CI (Horan et al., 2005).

An interesting feature of 24-mo CI systems was the effect on milk solids composition. As seen in Figures 1 and 3, milk protein and milk fat concentration both increased, whereas milk lactose concentration declined in tandem with decreasing milk volume. Kolver et al. (2007) reported a trend for increasing protein concentration during extended lactation, but did not observe an effect on milk fat concentration. Auldist et al. (2007) reported an increase in milk protein concentration from mo 10 to mo 13 of lactation, but observed no further significant increases in milk protein concentration thereafter. The effects of higher concentrations of protein and fat, and in particular the improved ratio of protein to fat, would have a favorable effect on milk price. Lactose is the primary osmotic regulator of milk volume, and it was expected that lactose concentration would decline as lactation progressed. Milk lactose concentrations are used as a proxy for suitability of milk for processing in Ireland; a bonus is paid or a penalty is inflicted for milk lactose concentrations above or below certain thresholds (approximately 4.35 and $4.2 \%$, respectively). In the later stages of lactation, milk lactose concentrations were in the range where no penalty was inflicted.

The milk production data from the current study indicated that only a small proportion of cows were capable of completing 22-mo lactations on a low-input pasture-based system, but almost $50 \%$ of cows were capable of lactating for 20 mo. The most profitable pasture-based systems achieve over $6,000 \mathrm{~kg}$ of milk

Table 6. Correlation between descriptors of the lactation curve and animal factors with cumulative milk yield and cumulative milk solids (MS) yield in extended lactations in a seasonal-calving pastoral system

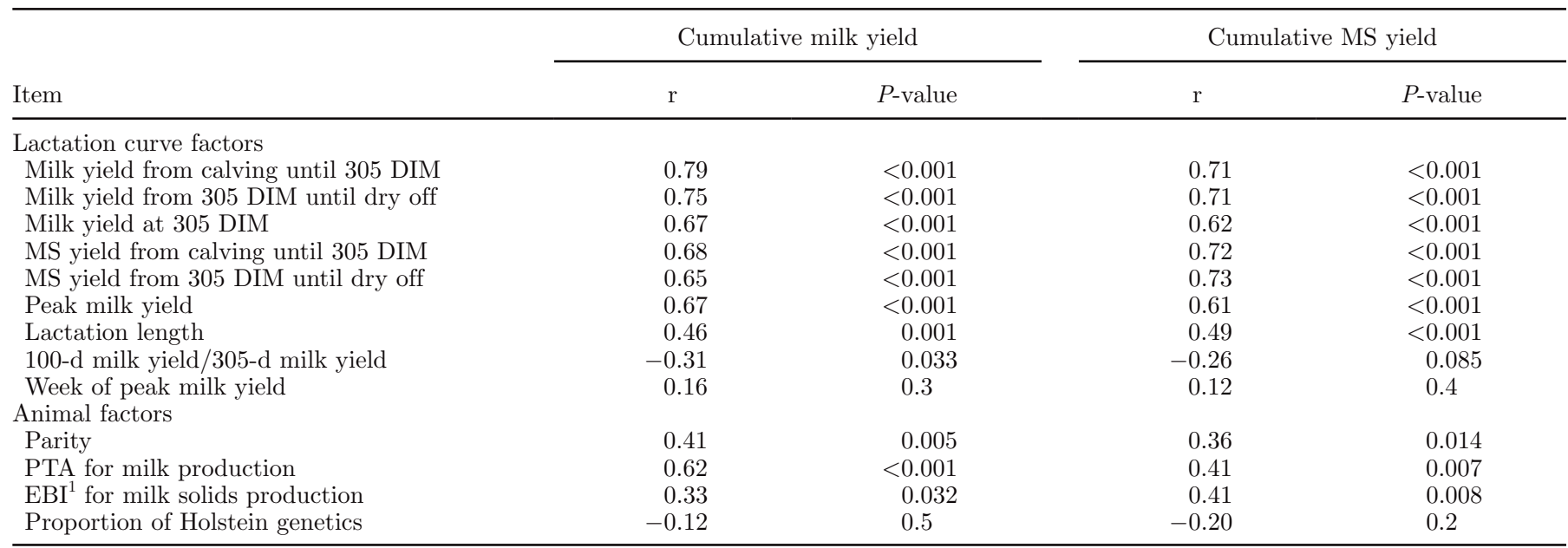

${ }^{1} \mathrm{EBI}=$ Economic Breeding Index. 
Table 7. Multiple regression models for cumulative milk yield and cumulative milk solids yield in extended lactations in a seasonal-calving pastoral system

\begin{tabular}{|c|c|c|c|c|c|c|}
\hline \multirow[b]{2}{*}{ Item $^{1}$} & \multicolumn{3}{|c|}{ Cumulative milk yield } & \multicolumn{3}{|c|}{ Cumulative milk solids yield } \\
\hline & $\begin{array}{l}\text { Parameter } \\
\text { estimate }\end{array}$ & $\mathrm{SE}$ & $P$-value & $\begin{array}{l}\text { Parameter } \\
\text { estimate }\end{array}$ & SE & $P$-value \\
\hline Intercept & 2,580 & 931 & 0.0083 & 97.3 & 91.7 & 0.29 \\
\hline Cum_305D_MY & 0.78 & 0.15 & $<0.001$ & & & \\
\hline PTA_Milk & 3.47 & 1.27 & 0.0093 & & & \\
\hline MY_305D & 127 & 47 & 0.0104 & 11.24 & 3.70 & 0.004 \\
\hline Cum_305D_MS & & & & 1.21 & 0.22 & $<0.001$ \\
\hline Parity (Par2) & & & & -98.6 & 41.3 & 0.022 \\
\hline Parity (Par3) & & & & -121.9 & 45.0 & 0.010 \\
\hline $\mathrm{R}^{2}$ & & 0.74 & & & 0.66 & 0.010 \\
\hline
\end{tabular}

volume and $500 \mathrm{~kg}$ of milk solids (fat + protein), with good reproductive performance in a short breeding period that facilitates calving and return to pasture in early spring, thus synchronizing the supply of and demand for feed (McCarthy et al., 2007). In the current study, R1 cows (i.e., the highest yielding cows) were capable of producing the equivalent milk volume and milk solids of 2 lactations with 12-mo CI in an extended lactation with a 24-mo CI. This result indicates that modern high-genetic-merit cows are capable of lactating for considerably longer than the 240- to 300-d lactations observed in seasonal-calving pasture-based systems. Thus, extended lactations could represent a viable alternative to culling and replacing high-producing cows that fail to become pregnant during a short breeding period.

\section{Fertility}

Declining fertility has resulted in extended lactations in confinement TMR-based year-round calving systems for many years. Year-round calving systems confer

Table 8. The effect of 24-mo calving interval systems on overall profitability for each individual year in a seasonal-calving pastoral system

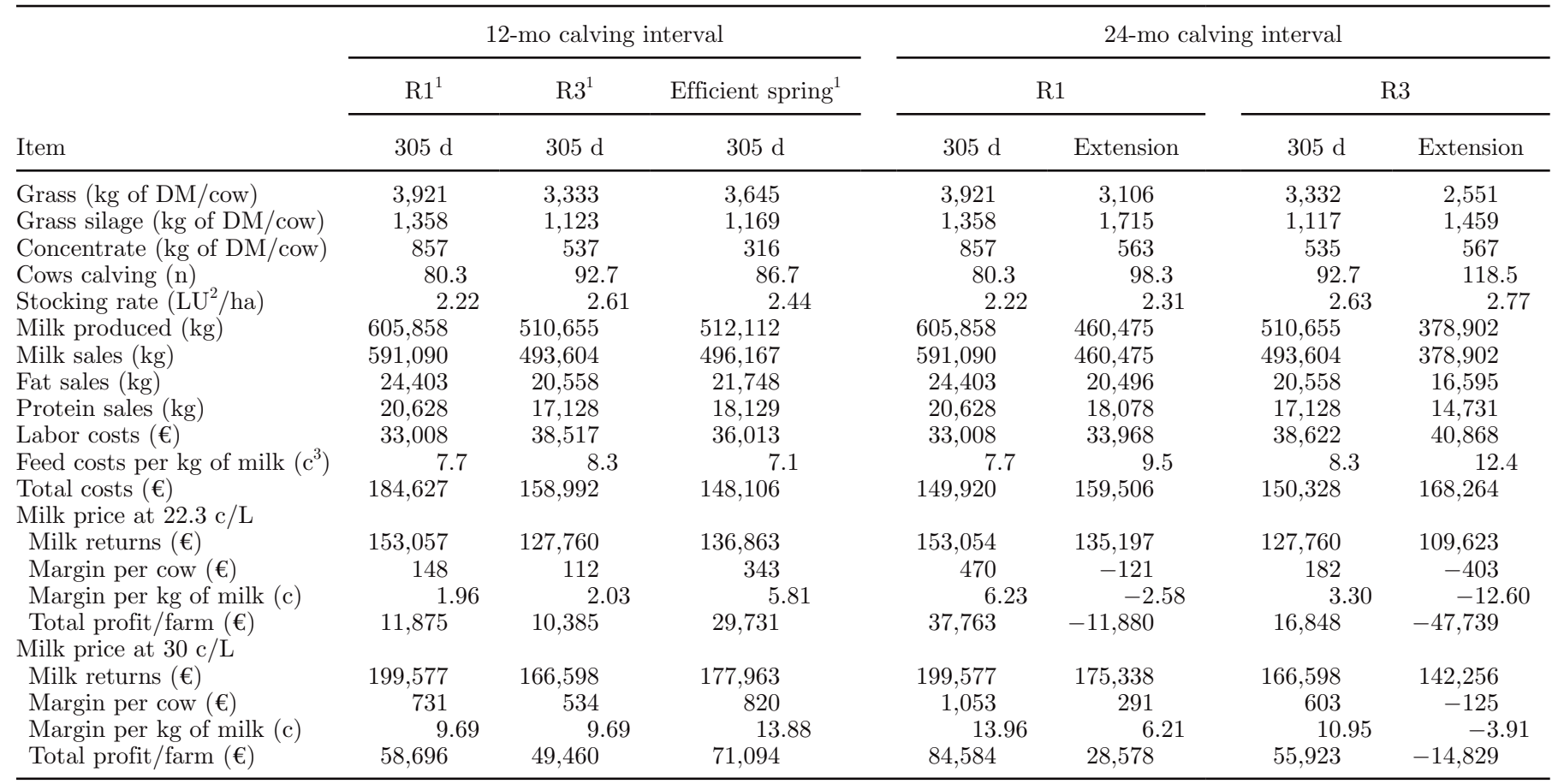

${ }^{1} \mathrm{R} 1=15$ highest cumulative milk solids production (CMSP); R3 = 16 lowest CMSP; data for efficient spring system are taken from McCarthy et al. (2007).

${ }^{2} \mathrm{LU}=$ livestock unit.

${ }^{3} \mathrm{c}=$ euro cents. 
greater flexibility than seasonal-based systems when fertility is suboptimal. The majority of dairy cows in Ireland $(>90 \%)$ are in spring-calving seasonal systems of production, and the diet is primarily grazed grass with limited use of alternative feeds. At the end of a typical 10-mo lactation when producers are faced with a large proportion of cows that failed to become pregnant during the preceding breeding period, the choices available are: cull the nonpregnant cows and replace with heifers or purchased cows; or continue milking the nonpregnant cows for an additional 12-mo extended lactation period and rebreed the cow during the spring to result in a 24 -mo CI.

Extended lactation was proposed as a strategy to avoid high culling rates caused by infertility in seasonally calving herds and cows in confinement systems (Knight, 2001; Borman et al., 2004). In traditional seasonal-calving systems, cows are inseminated at or near the time of peak milk yield, generally coinciding with nadir BCS. Body condition and BCS loss influence reproductive performance (Berry et al., 2003; Buckley et al., 2003). Cows with high genetic potential for milk production are genetically programmed to preferentially partition nutrients to the mammary gland for longer periods into lactation at the expense of body reserves and are typically below target BCS during the breeding period. As a result, they have reduced conception rates and an overall reduction in fertility performance
(Buckley et al., 2003; Evans et al., 2006). In the current study, none of the cows successfully established and maintained a pregnancy during the yr 1 breeding period (average 2.8 inseminations per cow). In the second breeding period in yr 2 , conception rates to first service averaged $52 \%$, and although the number of animals was small, there was no indication that reproductive performance was affected by winter feeding treatment or milk production rank. This indicated that reasonable fertility performance could be achieved with these cows, but that a longer interval between parturition and breeding was required. This broadly supports Kolver et al. (2007), who reported improved reproductive performance for both New Zealand and North American strains of Holstein-Friesian cows during the breeding period of an extended lactation compared with the breeding period of a 12-mo CI.

\section{Financial Analysis}

Milk production systems are composed of complex interactions between a series of individual biological and mechanical components. One system may be optimal in one environment but not in another for a range of economic, policy, environmental, or biological reasons. This results in huge variation in the optimal systems of milk production throughout the world. In most countries the optimal systems are developed around maximizing

Table 9. The annualized herd effect on overall profitability with $30 \%$ recycling for $\mathrm{R} 1$ and $10 \%$ recycling for R3 in extended lactations in a seasonal-calving pastoral system

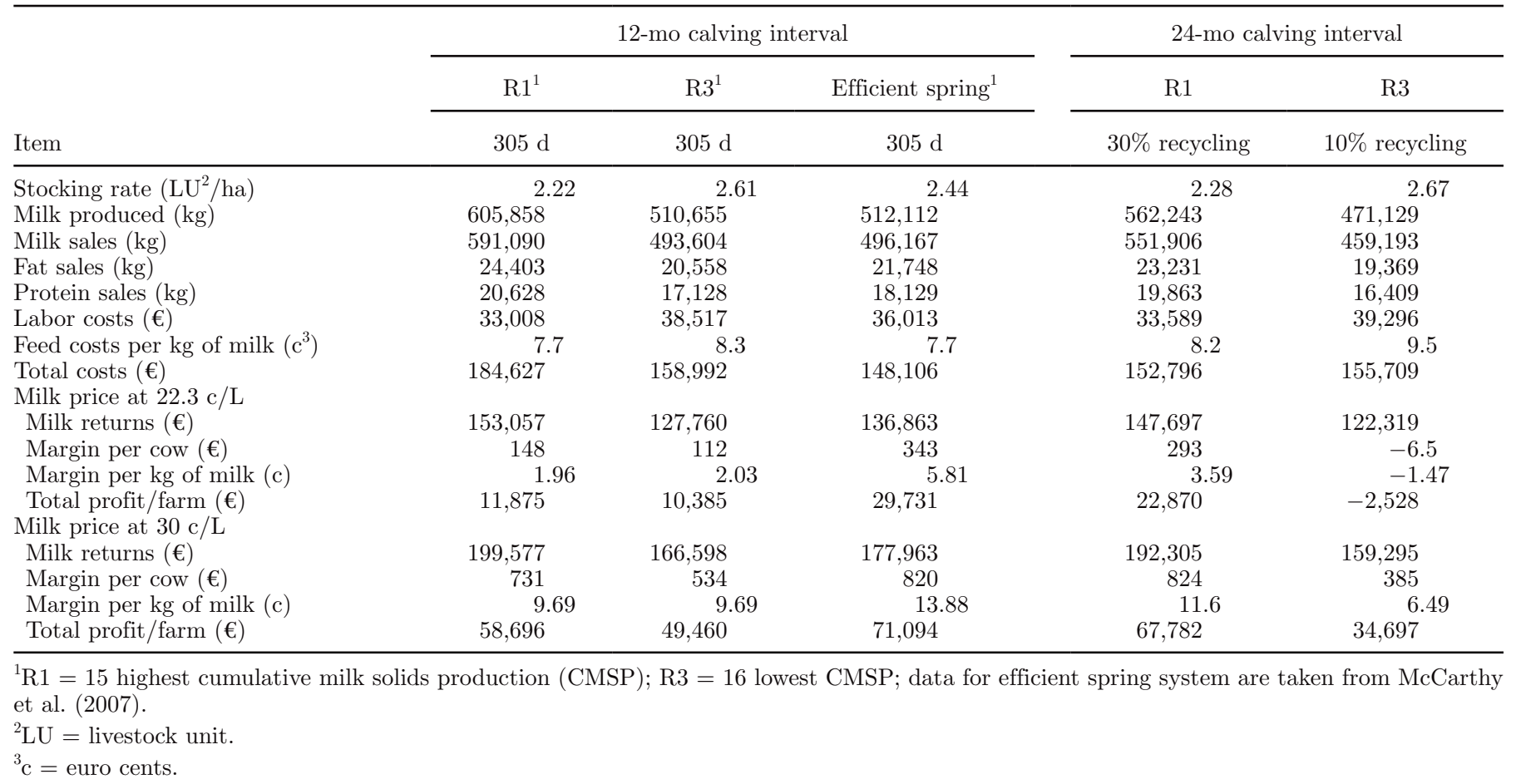


output per cow, but optimal systems in New Zealand and Ireland revolve around maximizing the utilization of grass in the diet and minimizing costs of production (Dillon et al., 2005). The additional costs or increased profit associated with systems of milk production that contain extended lactations will be dependent on several factors, including the system of milk production on the farm, the milk price and milk pricing regimen operated, additional labor costs, and the overall fertility of the herd.

Within grass-based systems of milk production, the effect of extending lactations beyond $305 \mathrm{~d}$ distorts the synchrony between supply of feed in the form of pasture and the requirement for feed to produce milk, which will ultimately lead to increased costs of production (Borman et al., 2004). In systems in which the relative costs of grazed grass, conserved feed, and concentrate are not different, the increased costs will not be substantially increased with 24-mo CI systems. This study has shown that high-producing R1-type cows were most suited to extended lactation systems, supporting work from New Zealand (Kolver et al., 2007). The results of the current study indicate that cows suited to 24-mo CI systems were capable of achieving peak milk yields of approximately $40 \mathrm{~kg} / \mathrm{d}$ and cumulative milk yields during the initial 10-mo lactation period of approximately 7,200 $\mathrm{kg}$, maintaining milk yields of $>20 \mathrm{~kg} / \mathrm{d}$ at 305 DIM, and having a PTA for milk yield of $+225 \mathrm{~kg}$. Cows with lower production potential were not profitable in 24-mo lactation systems and should instead be culled.

Methods of milk payment aimed at distorting the seasonal nature of milk production can alter the competitiveness of one system over another. Specific schemes aimed at increasing the production of milk out of season in seasonal systems of milk production are largely developed on a contract basis to produce milk for specific fresh products that require a supply of milk year round. This study has shown that at higher milk prices the competitiveness of extending the lactation increases. Price volatility is expected in Irish milk production systems as a result of the relaxation of the market management regimens within the European Union's Common Agricultural Policy; as a consequence, optimal systems will have to be able to sustain low milk prices for considerable periods of time.

Infertility and the associated costs affect the profitability of milk production systems worldwide. An economic analysis by Evans et al. (2006b) across 14 commercial dairy herds in Ireland from 1990 to 2003 showed that their overall profitability per liter of milk produced did not improve over the period because of declines in reproductive performance, even though milk yield per cow increased. The current study indicated that in seasonal calving systems in which herd fertility is low, 24-mo CI systems for cows not pregnant could be a good short-term method of reducing the costs associated with infertility. Yet, the results indicated that 24-mo CI systems will be substantially less profitable than systems with a 12 -mo CI, and that this is the optimum system to strive to achieve.

\section{REFERENCES}

Auldist, M. J., G. O'Brien, D. Cole, K. L. Macmillan, and C. Grainger. 2007. Effects of varying lactation length on milk production capacity of cows in pasture-based dairying systems. J. Dairy Sci. 90:3234-3241.

Bauman, D. E., S. N. McCutcheon, W. D. Steinhour, P. J. Eppard, and S. J. Sechen. 1985. Sources of variation and prospects for improvement of productive efficiency in the dairy cow: A review. J. Anim. Sci. 60:583-592.

Berry, D. P., F. Buckley, P. Dillon, R. D. Evans, M. Rath, and R. F. Veerkamp. 2003. Genetic relationships among body condition score, body weight, milk yield, and fertility in dairy cows. J. Dairy Sci. 86:2193-2204.

Borman, J. M., K. L. Macmillan, and J. Fahey. 2004. The potential for extended lactations in Victorian dairying: A review. Aust. J. Exp. Agric. 44:507-519.

Buckley, F., K. O'Sullivan, J. F. Mee, R. D. Evans, and P. Dillon. 2003. Relationships among milk yield, body condition, cow weight, and reproduction in spring-calved Holstein-Friesians. J. Dairy Sci. 86:2308-2319.

Butler, W. R. 2003. Energy balance relationships with follicular development, ovulation and fertility in postpartum dairy cows. Livest. Prod. Sci. 83:211-218.

Dillon, P., S. Crosse, G. K. Stakelum, and F. Flynn. 1995. The effect of calving date and stocking rate on the performance of springcalving dairy cows. Grass Forage Sci. 50:286-299.

Dillon, P., J. R. Roche, L. Shalloo, and B. Horan. 2005. Optimising financial return from grazing in temperate pastures. Pages 131147 in Utilisation of Grazed Grass in Temporal Animal Systems, Proceedings of a satellite workshop of the XXth International Grassland Congress, Cork, Ireland. Wageningen Academic Publishers, Wageningen, the Netherlands.

Esslemont, R. J., M. A. Kossaibati, and J. Allcock. 2001. Economics of fertility in dairy cows. Occ. Publ. 26. British Society of Animal Science, Galway, Ireland.

Evans, R. D., P. Dillon, D. P. Berry, M. Wallace, V. Ducrocq, and D. J. Garrick. 2006a. Trends in milk production, calving rate and survival of cows in 14 Irish dairy herds as a result of the introgression of Holstein-Friesian genes. Anim. Sci. 82:423-433.

Evans, R. D., M. Wallace, L. Shalloo, D. J. Garrick, and P. Dillon. 2006b. Financial implications of recent declines in reproduction and survival of Holstein-Friesian cows in spring-calving Irish dairy herds. Agric. Syst. 89:165-183.

Foote, R. H. 1996. Review: Dairy cattle reproductive physiology research and management-past progress and future prospects. J. Dairy Sci. 79:980-990.

Horan, B., P. Dillon, P. Faverdin, L. Delaby, F. Buckley, and M. Rath. 2005. The interaction of strain of Holstein-Friesian cows and pasture-based feed systems on milk yield, body weight, and body condition score. J. Dairy Sci. 88:1231-1243.

Jarrige, J., ed. 1989. INRAtion. V2.7. Microsoft computer program of ration formulation for ruminant livestock. 1. Dairy cows (J. B Coulon and P. Faverdin). 2. Sheep (F. Bocquier and A. Brelurut). 3. Growing and finishing cattle (D. Micol, J. Robelin, and J. Agabriel). 4. Suckler cows (J. Agabriel). 5. Goats (D. Sauvant). J. Agabriel, P. Champciaux, and C. Espinasse, ed. CNERTA, Dijon, France.

Kennedy, J., P. Dillon, K. O' Sullivan, F. Buckley, and M. Rath. 2003. The effect of genetic merit and concentrate feeding level on reproductive performance of Holstein-Friesian dairy cows in a grass based milk production system. Anim. Sci. 76:297-308. 
Knight, C. H. 2001. Lactation and gestation in dairy cows: flexibility avoids nutritional extremes. Proc. Nutr. Soc. 60:527-537.

Kolver, E. S., J. R. Roche, C. R. Burke, J. K. Kay, and P. W. Aspin. 2007. Extending lactation in pasture-based dairy cows: I. Genotype and diet effect on milk and reproduction. J. Dairy Sci. 90:55185530 .

McCarthy, S., B. Horan, P. Dillon, P. O'Connor, M. Rath, and L. Shalloo. 2007. Economic comparison of divergent strains of Holstein-Friesian cows in various pasture-based production systems. J. Dairy Sci. 90:1493-1505.

Royal, M. D., A. O. Darwash, A. P. F. Flint, R. Webb, J. A Woolliams, and G. E. Lamming. 2000. Declining fertility in dairy cattle: Changes in traditional and endocrine parameters of fertility. Anim. Sci. 70:487-501.

Shalloo, L., P. Dillon, M. Rath, and M. Wallace. 2004. Description and validation of the Moorepark Dairy System Model. J. Dairy Sci. 87:1945-1959.

Teagasc. 2008. Management data for farm planning, Teagasc, Oakpark, Carlow, Ireland.

van Knegsel, A. T., H. van den Brand, J. Dijkstra, S. Tamminga, and B. Kemp. 2005. Effect of dietary energy source on energy balance, production, metabolic disorders and reproduction in lactating dairy cattle. Reprod. Nutr. Dev. 45:665-688. 